\title{
The Dongola Expedition of 1896
}

\section{Captain A. Hilliard Atteridge}

To cite this article: Captain A. Hilliard Atteridge (1897) The Dongola Expedition of 1896, Royal United Services Institution. Journal, 41:232, 669-689, DOI: 10.1080/03071849709416035

To link to this article: http://dx.doi.org/10.1080/03071849709416035

$$
\text { 曲 Published online: } 11 \text { Sep } 2009 .
$$

Submit your article to this journal $\pi$

LII Article views: 10

Q View related articles $₫$ 


\title{
THE JOURNAL \\ OF THE
}

\section{ROYAL UNITED SERVICE INSTITUTION.}

\begin{tabular}{lll}
\hline VoL. XLI. JUNE, 1897. & No. 232.
\end{tabular}

[Authors alone are responsible for the contents of their respective Papers.]

\author{
THE DONGOLA F F PEDITION OF 1896. \\ By Captain A. HILLIARD ATTERIDGE (London Irish Rifles), \\ Special Correspondent for the "Daily Chronicle" \\ - during the Expedition. \\ Wednesday, Fcbruary 17th, 1897. \\ General Sir Frederick Stephenson, G.C.B., \\ in the Chair.

\section{LE.CTURE.}

THE Dongola province, once the most fertile region of the Upper Nile, may be said to extend from the rapids of the Batn-el-Hagar desert to the Fourth Cataract. It thus stretches along some 400 miles of winding river, the narigation of which at high Nile is interrupted by no serious barrier. The northern districts of the province between the Batnel-Hagar and the Third Cataract are known as the Dar Sukkot and the Mahassa. South of Hannek begins the Dar Dongola--the Dongola district in the narrower acceptation of the term. Still further south, as we approach the Fourth Cataract, we enter the Shaiggiyeh country.

The founder of Mahdism, Mohammed Ahmed, and its most brilliant soldier, Abderrahman Waden-Nejumi, were Danagla tribesmen, that is, men of the Dongola province. The district passed from Egyptian rule into the power of the Khalifa when, after our failure to relieve Khartoum, the frontier of Egypt was withdrawn to Wadi Halfa.

The British rearguard, under General Brackenbury, left the town of Dongola on July 5th, 1885 . The Dervish vanguard was then at Merowi. On August 17 th - six weeks after our retirement-3,000 fighting men, under the Emir Abd-el-Mejid el Khalik, marched into Dongola:

roL. XLI.

$2 \mathrm{U}$ 
Thence the enemy gradually overran the whole of the province. At first an attempt was made to hold the country as far south as Kosheh against them, mainly with a view to keeping the railway working to Akasha. General Grenfell's victory at Ginnis (December 30th, 1885) checked for awhile the Mahdist advance. But the Egyptian posts along the river were withdrawn at the end of the cool season, and by the middle of April, 1886, the valley of Khor Moussa, five miles south of Wadi Halfa, was the frontier of Egypt.

There were thus almost exactly ten years between the evacuation of the Dongola province and its reconquest in 1896.

Wadi Halfa had been chosen as the place for the Egyptian frontier garrison because, situated as it is at the head of the long reach of the Nile between the First and Second Cataracts, it could be kept all the year round in communication with the north by steamer; the sandy plain that surrounds it on the land side made it easy to defend; and the hundred miles of wild desert to the southward made the adrance of a large hostile force on that side extremely difficult.

It was by the other bank of the Nile that the Dervishes attempted the invasion of Egypt in 1889, thus trying to get round to the north of Halfa without coming within range of its forts. The rictory of Toski (August 3rd, 1889) nut an end to the enterprise. That fight marked the furthest north of the Dervish movement on the Nile. During the campaign of Toski the enemy's camp near Sarras was broken up and an Egyptian garrison at Sarras Fort became the furthest outpost of Halfa. No permanent adrance bejond that point was made by the Egjptian Army till the campaign of last year.

Suarda, 98 miles south of Sarras, was during this interval of seren rears, the advanced post of the Mahdist power on the Nile. 'The Emir who commanded at Dongola always kept a picked force at Suarda, whence parties of raiders would cross the Batn-el-Hagar desert, usually watering their horses and camels and filling their water-skins at Akasha, where they sometimes had a camp for months together. Ambigol Wells, in the desert on the old railway line, was another watering place. Long intervals divided these raids, but there was never peace or safety on the frontier. The villagers living within the Egyptian outposts were counted by the Dervish leaders as among "the enemies of God," with whom it was meritorious to wage a war of plunder and extermination. Even in the Dar Sukkot, between the southern edge of the Batn-l-Hagar and the garrison at Suarda, miles of river bank were made desolate by the raiders, who lived at free quarters on the inhabitants. The water-wheels were broken up and burned in the Dervish camp-fires, and the people, unable to till their fields, abandoned their homes. Far to the north, between Halfa and Korosko, the safety of the riverside villages was chiefly secured by the constant activity of the four stern-wheel gun-boats that patrolled the Nile.

Such a state of things could not last. Sooner or later an attempt was sure to be made to destroy the nest of brigands at Suarda and recover the Dongola province. But no one expected that this attempt 


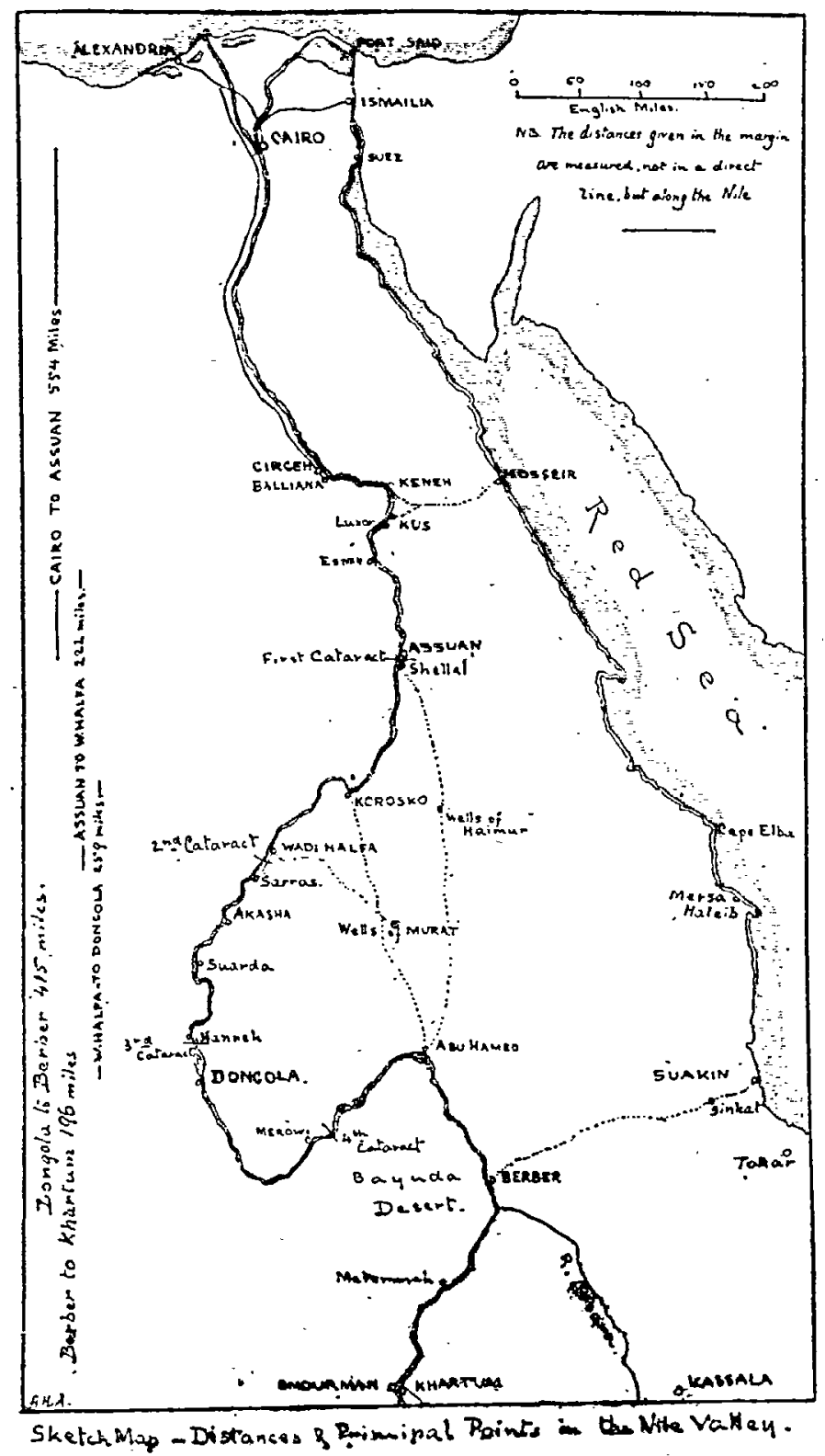

2 U 2 
would be made at the moment when it was actually undertaken. The relatively cool winter months are the time for campaigning in the Soudan. Except.at or near.high Nile.it is impossible to pass even a fairly large boat over the cataracts, and all river traffic between them is difficult and tediously slow. But it was near the end of the cool season, and when the Nile was almost at its lowest that the orders for the advance into the Dongola province were sent from England.

Political rather than military reasons dictated this step, and we do not discuss politics here. Let me simply note that it was on March 1st, 1896, that the Italians suffered their disastrous defeat at Adowa. Then came news of a Dervish movement against Kassala. The Italians appear to have contemplated the evacuation of the place, when our Government arranged with that of Egypt for what was at first described as an advance to Akasha with a view to diverting the attention of the Khalifa from Kassala. But the advance to Akasha soon dereloped into the Dongola Expedition.

The Sirdar received his orders by telegraph late on the evening of March 13th. The Expedition had to be, as it were, improvised at a moment's notice, and under the most adverse conditions. There could not have been a more trying test of the Egyptian headquarter staff and of the organisation of the new army. Both stood the test admirably.

The problem to be solved was this: - To concentrate a strong fighting force with sufficient transport and supplies at an advanced base near the southern edge of the Batn-el-Hagar desert, so as to be in a position to attack and destroy the Dervish force in the northern part of the Dongola province, and then march upon Dongola and clear the country of the enemy up to the Fourth Cataract.

The first base of operations was Cairo, nearly 800 miles from the front. Wadi Halfa was the advanced base at the outset of the Expedition. Akasha and Kosheh were the starting points of its later phases. We may thus divide the campaign into three distinct stages:-

1. Starting point, 'Halfa. - The crossing of the Batnel-Hagar desert, and the occupation and preparation of the advanced base at Akasha. From the middle of March to the beginning of June.

2. Starting point, Akasha-The breaking up of the Dervish camp at Ferkeh, the capture of Suarda, and the preparation of the advanced base at Kosheh. From the beginning of June to the last week of August.

3. Starting point, Kosheh.- The final advance on Dongola, and the pursuit of the enemy to.Debbeh and Merowi. From the "fast week of August" to the end of 'September.

First Stage of the CaMipaign.

In the middle of March, 1896, the Egyptian Army was, in round numbers, 16,000 strong, its organisation and the strength of the various arms being as follows:- 


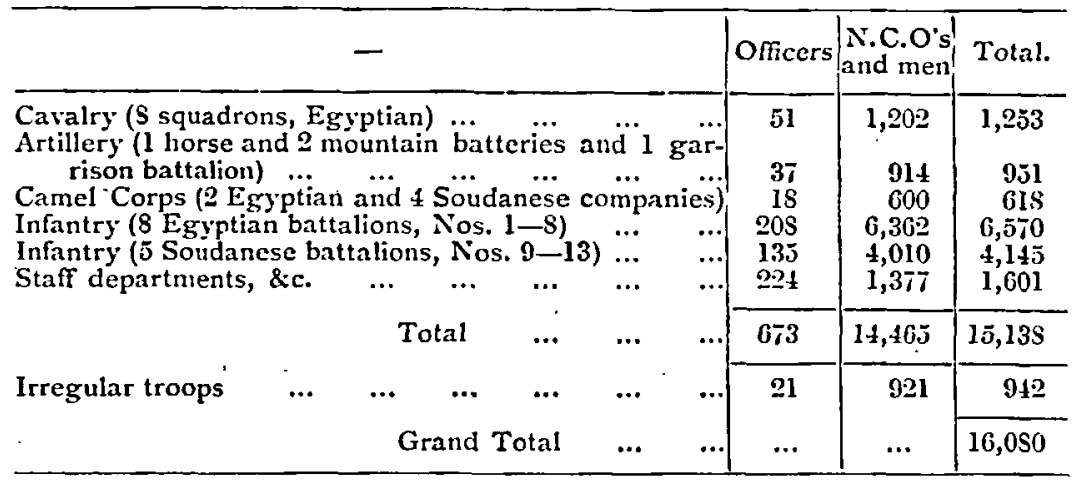

Of this force rather more than one-half was on the Nile frontier and the Red Sea coast. Suakin was held by a garrison consisting of the 1st and 5th Egyptians, the 9th and 10th Soudanese, a squadron of cavalry, and detachments of gunners and of the camel corps. Sarras, the southern outpost of Halfa, was held by a Soudanese battalion. At Halfa itself was the headquarters of the camel corps, a mountain battery, three battalions and a small force of caralry. Korosko was held by a detachment of infantry which had an outpost at Murat Wells, about half way along the camel track to Abu Hamed. This advanced post at Murat Wells was chiefly raluable as the starting point for watching any hostile morements along the bend of the Nile between Abu Hamed and Debbeh. It was connected with Korosko by a telegraph wire, and in case the wire should be cut by Derrish raiders there were tools, materials, and expert workmen always ready at both ends of the line to start off with a small escort and repair a break. Assouan had an infantry battalion in garrison, and the reach of the river between that place and Halfa was patrolled by four armed stern-wheelers, the "Tamai," the "Abu Klea," the "Teb," and the "Metemneh," all of which had done goud service in the Toski campaign, notably in the hard riverside fight at Argin.

According to the reports of the Intelligence Department, the enemy's forces in the Dongola province at the beginning of the jear were:-

\begin{tabular}{|c|c|c|c|c|c|}
\hline- & $\begin{array}{l}\text { Jehadia } \\
\text { (black } \\
\text { rifle: } \\
\text { men). }\end{array}$ & $\frac{\dot{2}}{\vec{E}}$ & $\begin{array}{c}\text { Sword } \\
\text { and } \\
\text { Spear- } \\
\text { men. }\end{array}$ & 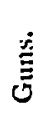 & $\underset{ت}{\stackrel{\Xi}{0}}$ \\
\hline $\begin{array}{c}\text { Under the Emir Nohammed Wad } \\
\text { Bishara at Dongola } \ldots \\
. .\end{array}$ & 2400 & 500 & 5000 & 8 & 7900 \\
\hline $\begin{array}{c}\text { Under his Lieutenant the Emir } \\
\text { Hammuda Idris at Suarda ... }\end{array}$ & 250 & 100 & 1000 & 一 & 1350 \\
\hline Total $\quad \ldots \quad \ldots$ & 2650 & 600 & 6000 & 8 & 9250 \\
\hline
\end{tabular}


At Abu Hamed there was a garrison of 1,200 men (400 Jehadia, 100 cavalrs, and 700 sword and spearmen), with four guns. Opinions were divided as to whether or not these northern Dervish garrisons would be reinforced to any large extent from the Dervish-main Army at Omdurman.

The Sirdar opened the campaign by directing Hunter Pasha to seize and hold Akasha with a detachment of the forces already on the frontier. But before describing this first advance let me note what was being done at Cairo and along the line of communications in the way of preparation for the subsequent operations.

The railway was working to Sarras. Beyond that point it had been destroyed by the Dervishes, who pulled up and bumed the sleepers, carried off all the smaller ironwork, but left the rails lying beside or on the track. Sarras was in telegraphic communication with Halfa. The forts at Khor Moussa and Gemai protected the railway and the line of communication between Haifa and its outpost.

Colonel Archibald Hunter was in command of the Nile frontier. Colonel Parsons at Suakin, had temporarily replaced Colonel Lloyd, who was in Cairo.

On the 1tth the first reserve of the Egyptian Army was called out. When an Egyptian has done his six years' service in the Army he is liable for five years' further service in the Police, and then passes for four years into the second reserve. But the number of time-expired men has of late years considerably exceeded that which is required for the recruiting of the Police, and the men who are not thus enrolled are sent direct to their villages from the Army; and form the first reserve. Last year all that were called back to the colours responded promptly to the summons-a marked and pleasing contrast to the old days when men called up for service in the Soudan had to be dragged in chains to the recruiting depôts. In one week enough men had rejoined to fill up all vacancies in the active Army, and out of the surplus two new battalions of Egyptian infantry had been formed, the 15th and the 16th. Later on, a new Soudanese battalion was formed,. partly of old soldiers, partly of recruits. It was drilled part at Tourah, part at Halfa. It was numbered as the 14th, the number hitherto belonging to the depôt or training battalion of the Esyptian Army. A company was also added to the camel corps by enrolling and training some $80 \mathrm{men}$, chiefly Shaiggiyeh, of the Khedive's guard. 'The 15 th was despatched to Suakin, and the two Soudanese regiments there, the 9 th and the 10 th, were ordered to proceed to the Upper Nile. They were to be conveyed by transports to Kosseir, march across the desert to Keneh, and reembark for Assouan and the front on Nile steamers and barges.

The 16th Battalion was ordered to proceed to Assouan in order to set free its garrison for service in the field.

All the Egyptian troops in lower Egypt were to be sent up the river. The British Army of occupation, with the Coastguard troops and Police, were to form the garrison. But the British Army was also to contribute directly to the Expedition, not only by supplying a consider- 
able number of special service officers; but also by sending to the front a Maxim battery, formed by uniting the machine gun sections of the Connaught Rangers and the North Staffordshire Regiment. The latter regiment left Cairo on March 22nd, reached Assouan on the 28th, and Wadi Halfa on April 2nd.

A railway construction battalion, 600 strong, was enrolled for the relaying of the line beyond Sarras. The men were mostly unskilled workmen, chosen for their physique, with a number of platelayers from the Egyptian railway department to act as foremen. British R.E. officers were to command them. Tools, spikes, etc., and a large quantity of sleepers were obtained from the works for the extension of the railway actually 'in progress in Upper Egypt, which was thus much delajed by the Expedition. Most of the railway iron required was already on the spot, where the Derrishes had left it.

The organisation of the camel transport was a more serious matter. It was estimated that about 4,000 camels would be required. To procure any large number on the frontier would be impossible, and in any case would only have tended to cripple the friendly tribes from whose cooperation much was expected. The experience of former campaigns had shown that some of the most serviceable animals were to be obtained in the north, one of the best kinds of camels for transport work being a cross breed between the desert and the delta camel. Officers were sent to purchase transport camels at various points along the river, and barges were covered in with light wooden sheds so as to make floating stables for their transport to Assouan, from the railhend at Balliana, from Keneh, Esneh, and other riverside landing places. Others were bought at Assouan. From that point most of them were marched to Halfa, but some were conveyed on barges, towed by the stern-wheelers.

Pack saddles for the camel transport, on a. new and improved model, were manufactured at the citadel workshops at Cairo. At the outset, before these were ready, native saddles were used, but I am told that the new saddles greatly diminished the number of sore backs, and proved in the end a source of considerable economy to the transport department.

Some 2,000 camel-men were gradually enrolled and organised in transport companies of 200 each. Thes men, the railway battalion, and the Arab friendlies were armiu with the Remington rifle of the old Army, which is also the reapon of the Egyptian Police and Coast-guard. The Feaptar of the Regular Army is the Martini-Henry.

As for the line of communications. For the first stage, from Cairo to Assouan, $\mathbf{5} 54$ miles, Messrs. Cook's fleet of powerful steamers was available, both for the actual conveyance of men and stores, and the towing of loaded barges. The sailing boats of the Nile were also utilised in considerable numbers, especially for the conveyance of railway sleepers and similar material. Or the river voyage could be shortened by utilising the $\mathbf{3 5 0}$ miles of railway from Cairo to Balliana, at the head of the completed line, which thus became a secondary base on the Lower Nile. Arrived at Assouan, eventhing had to be transhipped and con- 
veyed past the Second Cataract by land; men and animals marching the 7 miles, stores and material being mostly conreyed by the Shellal railway.

Shellal, at the head of the cataract, was the place of embarkation for the next stage of the river journey. A large flotilla of Nile boats, soren stern-wheel steamers, and four gun-boats, with a number. of barges, were available for the navigation of the river from Shellal to Halfa, about 220 miles. The steamer or gun-boat generally towed a barge on each side, and one, two, or three native river craft astern. Both below and above the First Cataract the shallow state of the Nile made progress slow. Steamers were frequently aground, and had always to tie up for the night.

At Halfa, stores for the front, and material for the railway were lauded, and conveyed by train to Sarras. By the time a consignment from Cairo reached that point it had travelled rather more than 800 miles, and had been transhipped at least four times.

The Sirdar, with Major Wingate, the chief of the Intelligence Department, and Slatin Pasha left Cairo for the front on March 22nd, and reached Haifa on the 29th. Colonel Rundle, the chief of the staff, followed them a week later, leaving Colonel Lloyd in charge of the base. Meanwhile, considerable progress had been made on the frontier.

On Sunday, March 15th, Colonel Hunter had issued orders for the oscupation of Akasha by a flying column, made up of-

The 13th Soudanese Infantry:

One squadron cavalty '(Broadwood's).

One company of the camel corps.

The 2nd Mountain Battery.

The mounted troops marched out to Gemai from Halfa ( 17 miles) on the ifternoon of the 16th. Next day they marched by Sarras to Semneh (23 miles), where they were joined by Major Collinson and the Soudanese Infantry; who were that day conveyed by train to Sarras and marched on the $T$ miles to Semneh. The column was thus complete. On the 18th it began its march along the river bank, and over the wild boulder-strewn nasses that traverse the rolcanic rocks of the Batn-elHagar. In the followiris yeeks this route was improved into a fairly practicable convoy track. Ifost of - it was then in such condition that men, horses, and camels had to more, sometimes to climb, slowly in single file. The camel corps and the cavalry scouted well to the front - and on the desert flank of the column. Each night it halted by the riser, so there was abundance of good water available. All other supplies it carried with it. Its marches were-

On the 18th, Semneh to Wadi Atira. 10 miles.

" 19 th, Atira to Tanjur. $\quad 231 / 2 "$,

As the distances show, the first part of the route was exceedingly difficult. The last day's work was a forced march. Resistance had been expected, but the Derishes were nowhere to be seen. The advance to 
Akasha was a complete surprise. The ruined fort, built in $188 t$, was occupied and repaired.

On the 22nd, the caralry and camel corps returned to Sarras to act as the vanguard of $a$ second column to Akasha. It started on the 24th, under the command of Major MacDonald, who had been selected as commandant of the advanced post. He had with him the cavalry' and the company of the camel corps, the 11th and 12th Soudanese Infantry, and a convoy of 600 camels, laden with supplies. 'They reached Akasha by a four days' march on the 28 th.

The day before, the first shot of the war had been fired from Akasha. A party of Dervish camel-men were sighted to the southward in the sandy khor that leads to Ferkeh. Promptly the Egjptian gunners of the mountain battery dropped a shell amongst them, and they retreated with one man killed and two wounded. Dervish scouts never showed theniselves again in daylight in sight of Akasha. With MacDonald in command, the camp was rapidly fortified, and grew stronger and stronger week by week till the advance to Ferkeh. Naturally Akasha is a bad position to hold, but in war one cannot always choose one's position for its natural advantages. As the head of the old railway line it had to be held, and the best was made of it by a system of defence of which I shall have to say something presently.

Akasha was linked with Sarras by a chain of smaller fortified camps and posts along the river, at Semneh, Wadi Atira, Ambigol, and Tanjur, Posts at Meliken-Nasr, Alimula, Sonki, and Okmeh were afterwards added to this line of posts, where the convoys could halt and camp in safety. But more than this, each post was a starting point for scouting parties that explored the desert eastward up to and beyond the old railway, while working parties from these camps improved the convoy route between them, till it gradually became something more like a road, and less like the dry bed of a boulder-strewn torrent.

The starting point of the convoys was Sarras, where every day one or two train loads of stores and railway material came up from Halfa. At first one convoy per week was all that could be attempted, but very soon two each week was the normal number, more transport being available. As a rule, the convoys consisted of three transport companies with 200 camels each. The camel's load was from 350 to $400 \mathrm{lbs}$. This is, I believe, much less than the load used in India; ; but in these desert marches there was a good deal of climbing over rocky passes, where the camel had not merely to carry; but to lift, the load, and where the collapse of one animal would block the track. Even with these lighter loads, there was a great difficulty in keeping the convoy closed up where the ground was at all rough. The day's march was about fifteen miles, the start being made at sunrise. The escort usually consisted of a squadron of cavalry and a small force of infantry, one or two companies But very often troops moring up to the front would accompany the convoy and considerably strengthen this escort. Along a great part of the way the convoy route was open to attack from the desert, notably along the 12 or 13 miles from Melek-en-Nasr to bejond 
the Sonki passes. Its safety was provided for by scouting well to the eastward bejond the track of the old railway. Later on, about the middle of May, the policy was adopted of diminishing the escort actually moving with the convoy, but watching the track at dangerous places with pickets or small permanent posts, the camel corps and the friendlies doing the scouting in the desert.

By this time, too, the steady advance of the railway had added considerably to the security of the northem part of the route, by practically establishing a new line of posts in the desert itself. At the same time the distance to be marched by the convoys was diminished, as first Murrat Wells and then the station at Ambigol Wells became the starting point.

The railway battalion had begun to work at the relaying of the line close to Sarras Fort at the beginning of April, first under the direction of Lieutenant Stephenson, R.E., and subsequently under that of Lieutenant Girouard, who came out from England as Director of Railways to the Expedition. Progress was at first slow, as the men had to be taught their work. The operntion was a good deal simplified by the fact that the rails were lying near the place where they had to be laid, and the earthwork of the line was practically uninjured. In places, drifted sand had to be shorelled off the track. At one point bejond Ambigol Wells, a wide gap had been cut through an embankment by the rainflood of a very local thunderstorm, sweeping down a khor. I say very local, for along the rest of the line there was no sign whatever of a rainfall during the ten years since it had been abandoned. The railway iron that had been lying all this time in the desert was clean and free from rust.

The rails were single-headed, with a wide flat base. They were iron faced with steel. New steel rails were used for the more southern sections of the line, and doubtless the whole railway will be relaid with this more modem material. The gauge is 3 feet 6 inches, somewhat narrower than that of the Egyptian railways, and the same as the Cape lines.

Between Ambigol and Akasha some miles of the line were intact, saved from destruction by the Dervishes through being buried in deep sand drifts, which had merely to be cleared away with basket and shovel.

In relaying the line the system of working was this: First the rails were laid end to end on the bank, sufficiently far apart for the sleepers to be put down between them. Every four or five rails were fastened together, but only one bolt was screwed through each fishplate and railend. . The sleepers were meanwhile placed in position, pegs driven beforehand at every hundred jards, marking the centre of the track. Gangs of men then lifted the rails on to the sleepers, and an officer saw the gauge was correct. No chairs were used, the rail being single-headed with a wide base. The hammer-men spiked them down direct on to the sleepers, and the second bolts were put through the fishplates. Then the last gang of all came along with shovels and crowbars, and the rails and sleepers lifted where necessary, and the ballast 
shovelled in and packed. When the work was in full swing one could see the line creeping steadily on as one stood by the track, for it was then growing at the rate of about a mile a day, but it was not till near the end of April that the railway battalion had acquired sufficient skill to make such a result possible.

The working of the railway was frequently interrupted by trains running off and temporarily blocking the track. A rapidly improvised line like this with very defective rolling stock could not be relied upon as a means of supply, unless there was such a large accumulation of stores at the railhead as would enable supply operations to be carried on during these temporary interruptions of traffic.

The protection of the railway works was confided to the 7 th Egyptian Battalion, under Colonel Fathi Bey, which camped with the railway battalion near the railhead and covered it with a line of pickets. This infantry guard was supplemented by a few cavalrymen, who formed Cossack posts on the hills to the extreme front. The station of Murrat Wells, reached by the railway early in May, was protected by a small fort and a couple of closed works, of stone breastworks topped with sandbags. When Ambigol Wells was reached towards the end of May, that more important, and also more exposed, position was protected by a fort mounting four heary Krupps and a couple of machine guns.

But the real safety of this double line of operations in the Batn. el-Hagar, the convoy track near the river, the growing railway line further inland, lay in the elaborate system of obtaining information, organised by Major (now Colonel) Wingate, the chief of the Egyptian Intelligence Department. It would be difficult to praise too highly the work he did, work to which the complete and unbroken success of the Expedition was largely due. The whole story, or even any great part of it, cannot be told till the Khalifa's power is finally broken. When it is written it will be stranger than any romance. From Suarda, from Dongola, from Abu Hamed and Berber through Ifurat, and from Omdurman itself, through the branch Intelligence Office at Suakin, there came the reports of the agents of the Department: Daring Arab and Soudanese spies, who had carried their lives in their hands for months, returned with detailed information of what was going on behind the enemy's border line, and means were found to send up the river assurances to the tribesmen of the Dongola province that the Egyptian Army was coming only to break the power of the intruding Baggaras; that life would be spared when battle was done; property respected, and all goods paid for in hard cash. Every important movement of the enemy was known at the Sirdar's headquarters almost as soon as it was ordered.

Further, the relations of the Department with the tribes along the Upper Nile enabled the Sirdar to organise a small and extremely efficient force of friendly Bedawin allies to guard the desert tracks on the flanks of the Expedition, and to make bold reconnaissances up to and into the enemy's territory: Thus Abdul Azim Bey, with 200 Ababdeh scouts started from Murat Wells in the Korosko desert early in April, rode 
southwards and westwards till he struck the Nile at Sehirri island, marched into the Shaiggiyeh country, and found no traces of the enemy, but heard from the people that some reinforcements had passed down to Dongola. He assured them that the Egyptians would soon be in Dongola as conquerors, and was assured by them in turn that they were longing to see the Baggaras driven back into Darfur. Then he returned to Murat, revisiting the Shaiggiyeh country again by the same route after Ferkeh. Abdul's scouts from the Murat outpost watched $A$ bu Hamed throughout the campaign, and the friendly chief asked eagerly for permission to surprise the place, saying that if he had a company of Soudanese from Murat to back him he could do it easily.

Another Ababdeh Sheik, Bishir Bey, watched the roads that run from Assouan by the Wells of Haimur to Berber. Haimur was. his centre of operations; he had a post at the Wells of El Koleib, on a track by which Dervish raiders had often got down to the Nile villages near Assouan. Another post held the Wells of $\mathrm{El}$ Ongat. He pushed reconnaissances south along the Berber track, but found only a few of the enemy near the Wells of En Negem, hostile scouts who retired as soon as they were sighted. Before Bishir occupied El Haimur, the wire between Murat and Korosko was cut two or three times. The presence of the A babdeh posts on the flank of the line made it safe for the rest of the campaign.

On the other flank, the Expedition was protected by the river. But beyond the Nile there is an important caravan track which comes down from the south through the Selima oasis and the great oasis of Khargeh, reaching the river near Assiout. In 1881 Colonel Colville reconnoitred this route and reported that it was practicable for a force of not more than a thousand men. Larger caravans working in detachments used to follow it in the old days. In order to make quite sure that it was not used by Derrish raiders or even by scouting parties, the Ababdeh Fuggara friendlies, working on the west bank, watched it, and early in the campaign pushed a reconnaissance close up to the Selima oasis.

The telegraph was carried beyond Sarras in the third week of April, being rapidly laid by Lieutenant Manifold, R.E., along the convoy route.

Laying a telegraph line was in one way fairly easy work. There was no trouble about insulation. The dry sand was almost as good as a sheet of glass for the purpose, so a strong galvanised wire was simply laid along the ground. Later on it was raised on poles to keep it out of the way of accident from passing camels, but even then no insulators were used. Lying on the ground the wire gave far better results than the most carefully insulated English lines. The difficulty was really to get it "to earth," and the only way of doing this was to run some yards of the wire into the river. All the land was too dry.

$A$ telephone wire was afterwards laid along the railway. In case of either of these wires being cut there was an organised system of signalling. Jebel Bringo, a high mountain in the Batnel-Hagar, near Murat Wells, could communicate with Sarras, and Sarras passed on the signals by wire to Halfa. Eren if that wire failed it could signal 
through Gemai. There is always good sunshine for the heliostat among those desert hills.

But the wires were never cut, and no attempt was made by the enemy on the convoy route or the railway line. The Dervishes showed indeed a strange lack of dash and enterprise. A single daring attack on a convoy in the early stages of the campaign might have led to a long delay in our subsequent advance, as, after such an experience, probably smaller convoys would have been used, marching more slowly, and with larger escorts.

In the Dongola province, till the end of April, the enemy's activity was confined to a few insignificant scouting expeditions near Akasha. In the direction of Suakin, Osman Digna in the beginning of April took the field, but failed to raise the local tribes, and after an unsuccessful engagement with the columns despatched against him from Tokar and Suakin, retired to the Atbara. His excursion into the province had, however, some effect on the campaign. The 9th Soudanese had already been transferred from the Red Sea to the Nile before Osman took the field, and the 10th were to follow, but they had to remain at Suakin, and were not moved to the Nile till the arrival of the Indian brigade set free the garrison for service with the Expedition.

All anxiety about Kassala was set at rest by Colonel Stevani's brilliant victory on April 2nd.

The first fight on the Upper Nile was the cavalry action on May-day near Akasha. In the middle of April the Dervishes had pushed a picked force of black riftemen (Jehadia) and Arab cavalry, camel-men, and sword and spearmen, to Ferkeh, a ruined village which they made the nucleus of their camp. Hammuda Irlris, who commanded there, sent back to Bishara at Dongola mendacious accounts of successful attacks on the outposts of Akasha, and there came pressing exhortations to him to attack and capture the place. All the while he appears to have been quarrelling with his sccond in command, Osman Azrak, and with the Emir who commanded the Jehadia. These dissensions in the Dervish camp are the most probable explanation of the enemy's strange inactivity in the early weeks of the campaign. In the last week of April the Intelligence Department got information that there would probably be a move on the next Friday, the Moslem Sabbath, which happened to be the 1st of May.

By that time Akasha was a strong, fortified camp. Beginning at the river bank there was an inner line of screens made of railway iron or small girders, stone breastworks, and wide belts of thorny zereba hedge. Beyond this were the outlying posts, a blockhouse on the high ground to the right, with a battery armed with two guns close to it, where there was a good view over the desert hills.' A heavy sand-bag breastwork, with the Maxim battery ready behind it, looked down Ferkeh Khor. Two small stoneworks carried on the line to another blockhouse on the left front, and thence the line ran back to the old fort. Outworks were constructed on a couple of rocky knolls beyond it, and there was an advanced work and look-out station half a mile beyond the general line up the Nile bank, and a small fort on the hill on the rest bank. The 


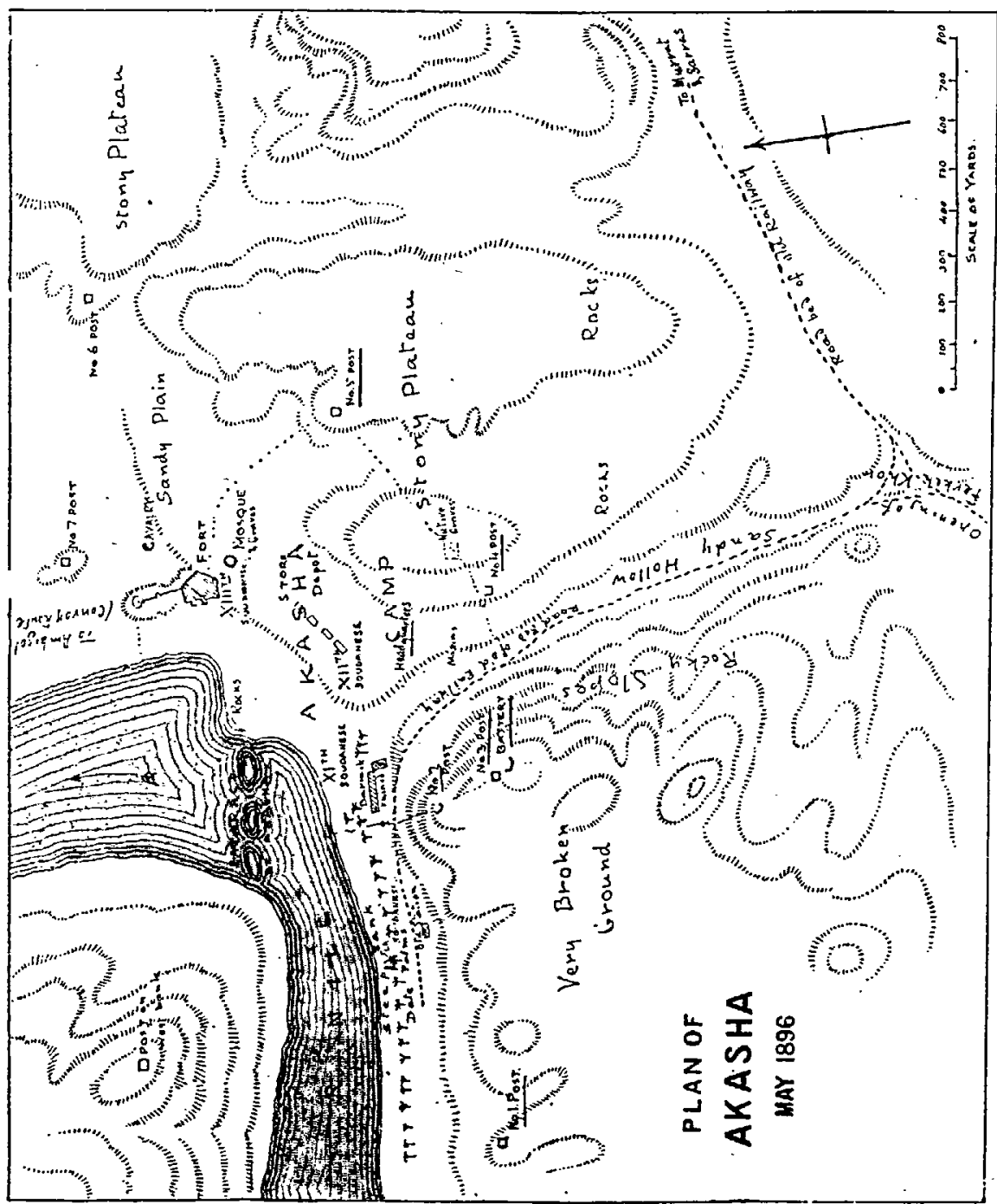


ranges in front of the works were plainly marked, and all the advanced posts had a good supply of water and cartridges.

Hammuda probably knew better than to try to rush such a place as this. But he had to do something, and he made a demonstration on Mayday with about 1,000 men, cavalry, camel-men, spearmen, and some riflemen. They were stopped six miles from Akasha in Ferkeh Khor by three squadrons of cavalry under Major Burn-MIurdoch. The ground where the action took place was utterly unfitted for ordinary cavalry tactics. It is about the roughest bit of ground in the whole valley. I rode over it later. and saw the Dervish horses still lying dead among the rocks, though it was some weeks after the action. The essential facts as to the fight may be given very briefly. Burn-Murdoch went out to look for the enemy, followed by half a battalion of. Soudanese in support. He got touch with the enemy's scouts, followed them up, and, halting his column, pushed on with a few men to see what they had behind them. He found the enemy 1,000 strong on ground where no cavalry in the world could charge. He rejoined his force, and was retiring along the Khor to rejoin his infantry before taking further action, when the Dervish cavalry, misinterpreting his motives, came after him. He faced his squadrons about, and the enemy retreated; a few men only on both sides got close enough to use their weapons, and a few Dervish desperadoes who would not retire were ridden down. The enemy's cavalry withdrew behind their infantry, who advanced firing. Burn-Murdoch met them and stopped them by dismounting his men and opening a heavy carbine fire from the rocks. The Dervishes then drew off. When the Soudanese came up it was decided not to advance further, as the men were exhausted with the intense heat. One of the Soudanese had just died of sunstroke. This repulse of a superior force of the enemy had an excellent effect on the whole of our army at the front.

\section{Second Stage of the Campaigs.}

During May the only movement made by the Dervishes was a halfhearted demonstration against the outposts at the railhead in the last week of the month. The railway had then reached Ambigol Wells, and as the simplest method of protecting its further progress south, and putting a stop to a series of raids which, according to the Intelligence Department reports, the enemy was now contemplating, it was resolved to break up the Dervish camp at Ferkeh in the first week of June.

There were nearly three months' provisions for 10,000 men accumulated in the depôt at Akasha, so a move southwards was fully justified. The possession of Ferkeh was further necessary in order to commence as soon as possible preparations for carrying the railway to the Nile bank above the Dal Cataract.

The prolongation of the railway bejond Ambigol Wells was temporarily suspended. The railway battalion and some companies of recruits took over the güard of the line of communications. The 6 th Egyptians were sent up to garrison Akasha. The rest of the Army, strengthened by the 10 th Soudanese from Suakin, was concentrated in the 
first days of June, in a great camp along the Nile, from Okmeh to Akasha.

If the Sirdar's object had been merely to clear the enemy out of Ferkeh, there would have been no need of such a large concentration to the front. I believe MacDonald, with the Soudanese Brigade, a mountain battery and the Maxims could have done it any time in May, though it would have cost a very hard fight, and more loss than was actually incurred on June 7 th. But the Sirdar meant not merely to get possession of Ferkeh, but to deal the Dervishes of the Dongola province a crushing blow; not simply to defeat, but to destroy their advanced force, and to follow up the victory by clearing the country of them right up to Suarda.

The orders for the advance to Ferkeh were issued on Saturday, June, 6th. Up to the last moment, though everyone knew a battle was impending, the secret was well kept in our own camp. The enemy seem not to have expected that the Sirdar would advance till the railway was finished. up to Akasha.

There are two routes from Akasha to Ferkeh, known respectively as the "desert route" and the "river route." Both start by the same sandy valley, the Ferkeh Khor, which runs nearly south out of the semi-circle of rocky hills that surrounds Akasha. About a mile out another valley, Khor Shargosheh, strikes off the right towards the Nile, and it is at this point the river route begins, so called, not because it follows the river bank, but because at three points it touches it. For a great part of the way it runs through the broken ground between Dal Mountain and the river. Dal Mountain is the highest point of a mass of hills, of which the mountains just south of Akasha form the northern; and Ferkeh MIountain the southern extremity. Along the valley eastward of this mass, and dividing it from another range of low hills, runs the desert route, which joins the river route close to Ferkeh.

The whole distance from Akasha to Ferkeh is about eighteen miles. The desert route was fairly easy ground for an army to traverse. But the river route, which at one point north of Sarkamatto village, ran along a mere shelf of rock above the river, must have secmed to the Dervishes all but impossible. This was doubtless one reason why the Sirdar choose it for the line of his main advance-for surprise was a large element in his plan.

His idea was to attack the Dervishes in two columns, one by the desert, the other by the river route. The desert column was composed chiefly of mounted troops, and was placed under the orders of the cavalry commander, Major Burn-NIurdoch. It was made up of the following troops:-

Captain Young's Horse Battery, 6 guns.

The North Staffordshire Machine Gun Section, 2 Maxims.

Six Squadrons of Cavalry, 800 sabres.

Major Tudivay's Camel Corps, 670 rifles.

The 12th Soudanese (Townshend), 717 officersand men, mounted on transport camels till they reached the scene of action. 
In all, Major Burn-.Murdoch had about 2,400 men in his column. His orders were that they were to be in position on the east of Ferkeh by half-past four o'clock on Sunday morning. The hour of sunrise was eighteen minutes past five; and they were told that about five o'clock they would hear the fire of the river column as it came into action. Burn-.IIurdoch was to keep his own force well back, so as to be out of the field of fire of the river column, and, as soon as he heard it, was to. open with his artillery on the Dervishes. He was especially to use his guns and Maxims, to prevent and break up by flank fire any attempt of the enemy to mass for a charge. As soon as Ferkeh village was taken he was to have his cavalry and camel-men ready to fall upon the retiring Dervishes, and pursue them southwards, preventing them rallying, and destroying or capturing as much as possible of their force.

The Sirdar took personal command of the river column. It was made up of two batteries of mountain guns (twelve pieces), two Maxims, manned by the 2nd Connaught Rangers, a few cavalrymen for scouting purposes, and for its main body Hunter Pasha's infantry division of three brigades of three battalions each.

\begin{tabular}{|c|c|c|}
\hline $\begin{array}{l}\text { 1st BrIGADE. } \\
\text { Ietcis. }\end{array}$ & $\begin{array}{l}\text { 2nd BRIGaDe. } \\
\text { MfacDonald. } \\
\text { 9th Soudanese. }\end{array}$ & $\begin{array}{l}\text { 3rd Brigane. } \\
\text { Maravell. } \\
\text { 2nd Egriptians. }\end{array}$ \\
\hline & 11th & 7th \\
\hline dist: & 13th & 8th \\
\hline
\end{tabular}

The total strength of the river column would be about seven. thousand men. In the rear of the $3 \mathrm{rd}$. Brigade marched the field hospital, carried by one hundred camels, and another hundred camels laden with the reserve ammunition.

To go into the details of the fight at Ferkeh would take up too much time. Suffice it to say that the Sirdar's plan worked out admirably. The ground over which the columns were to move had been carefully reconnoitred and mapped. The Intelligence Department had issued a memorandum to every officer giving a detailed account of the enemy's position, armament, organisation, and leaders, with a rough plan of their camp indicating the position of their outposts, which, as usual with the Arabs, were so close in as to be all but useless at night. The night march afforded an admirable test of the discipline of the new Egyptian Army: To reach its bivouac near Sarkamatto the nine battalions, the two mountain batteries, and the staff and hospital and reserve ammunition columns had to pass by starlight along a mere shelf of rock between a bold spur of the mountains and the upper reach of the Dal Cataract-a feat in night marching of which any army might be proud. At dawn the Dervishes were attacked, the infantry and the mountain batteries coming up the river bank, and then, after the fighting line had deployed, pivoting on their right so as to attack the desert front of the village as well as its north end. The heavy guns and the mounted troops were on the hills to the eastward. The Dervishes made a much greater use of rifle fire than in most of their previous battles; but, as they never have any rifle prac-

roL. XLI. 
tice and have never even dreamed of such a thing as fire discipline, their bullets found few billets. 'The Egyptian infantry marched, deployed and fired as if they were taking part in a big field day. 'The attack was made in close order, without any cxtension. "Steady drill" certainly scored a triumph in the way in which those well-drilled Egyptians advanced in line against the Dervish position, nearly all the rank and file of the purely Egyptian regiments being men who now heard the whistle of an enemy's bullets for the first time. The Dervishes tried onc or two minor rushes, but never massed for a grand charge in the Abu Klea style. The possession of so many rifles, and the experience of what rifle fire could do against them in our own Soudan battles, seem to have led to a change of tactics. They fought splendidly and lost heavily. Caught as they were by the double attack of the two columns, it would have been possible to have absolutely cut off all retreat to the southward. But the better plan was chosen of letting the délris of the Ferkeh force stream away to the southward, breaking up any attempts to rally, keeping the beaten Dervishes on the run and destroying their force piecemeal.

At 5 a.m. on Sunday the battle of Ferkeh was just beginning. At 5 a.m. on MIonday Burn-MIurdoch had captured Suarda; and fifty miles of the Nile valley, including the whole of the once rich Dar Sukkot district, had passed into the hands of the Egyptians. So great was the impression produced by the destruction of the picked force gathered at Ferkeh, and the fall of three-fourths of the fighting limirs who had been selected to command it, that no real stand was made after that against our advance in the Dongola province.

\section{Thikd Stage of the Campaign.}

Having described so fully the methods adopted and the results obtained in these first stages of the campaign, I may deal more briefly with its close.

During June, July, and the greater part of August, Suarda, fortified and garrisoned by MacDonald's Soudanese brigade, was the advanced post. The Dervishes abandoned their posts near the Kaibar Cataract in presence of an Egyptian cavalry reconnaissance in the middle of June, and henceforth their advanced positions were above the Third Cataract, Kerma on the east and Hafir on the west bank.

The railway reaçed Ahasha at the end of the third week of June. After this its progress was slower, as it was a case of laying a new line, not relaying an old one, and all the railway iron had to be brought up. The earth-works were constructed in advance by the Egyptian infantry. The line reached Ferkeh on July 25th and Kosheh on August 4th. A dockjard was organised there for the construction of the new steamers that were being sent out from lingland in sections.

There was a bad Nile, making the passage of the Second Cataract by the steamers exceptionally difficult, and considerably delaying the advance of the expedition. It had been hoped that the four stern-whecl gunboats and three of the other steamers would be up in July. It was not till August that they even began the ascent of the cataracts. 
Further delay was caused by a severe outbreak of cholera, which had never before penetrated to the Soudan." And, as if every possible difficulty was to be thrown in the way of the Sirdar's enterprise, those proverbially rainless deserts were suddenly swept by a series of rain storms which turned every khor into a raging torrent and swept away miles of the new railway on the eve of the general advance.

At length towards the end of August all was ready for the march upon Dongola. The gun-boat flotilla had been assembled above the cataracts at Kosheh, where one of the new boats from England armed with Q.F. guns was approaching completion. A large supply of stores had been collected at Kosheh railhead, and water depôts had been formed on the desert route from Kosheh camp across the bend of the Nile to Sandin Fenti. That place was occupied by the Soudanese brigade on August 23rd. They are said to have lost 29 by sunstroke in the desert march. This will give some idea of what Soudan campaigning in the summer means. The Sirdar's army had been strengthened by bringing up the North Staffordshire Regiment to the front, and by forming a fourth infantry brigade under Major David, R.MI.L.I., out of the 1 st and 5th Egyptians, and the 16th Reservists. The R.M.A., under Captain Oldfield, supplied a party of trained gunners for the flotilla, and the Navy was further represented by Commanders Colville and Robertson and Iieutenant Beatty, who commanded three of the stern-wheelers; Colville, as senior officer, having the chief command of the little fleet.

Even if the enemy had been disposed to make a serious stand their chance of anything like a long resistance was negatived by the Sirdar's having a powerful gun-boat flotilla to act with him. The fight at Ferkeh would not have lasted for two hours, as it did, if the river had been high that Sunday morning, and four steamers had been sending a shower of shells and a hail of machine-gun bullets into the Dervish flank and rear, and threatening to sweep their line of retreat with this murderous fire. On the Upper Nile he who holds the river holds the country on both sides to an extent that is probably not the case with any other river. Until Berber is passed there is not a single tributary stream flowing into the Nile. Except at the desert wells, which have usually a scanty supply, every drop of drinking water must come out of the river. Only small parties can trust to the desert wells, and these are far away from the banks. Where there is a belt of cultivated land, the water is supplied by irrigation channels fed by sakkijelh wheels on the river bank. To stop these wheels is to force whoever wants water to come down to the bank for it, and an army cannot draw water for its thousands of men and beasts under the fire of a hostile fleet of gun-boats, whose electric lights can watch the banks even during the hours of darkness. 'To retire along the river with a gun-boat fleet on the flank, or steaming ahead, would therefore

'It would not be easy to exaggerate the services rendered to the expeditionespecially at this trying time-by the Medica ${ }^{1}$ Officers attached to it, or to praise too highly their zeal, energy and self-sacrificing devotion to duty, in which one of the too small number lost his life. 
be destruction, and it was a safe prediction that once the flotilla passed any Dervish position it would be promptly evacuated by the enemy.

On August 27th, the 1st Brigade marched across the desert to Absarat. It was caught in the same storm that wrecked the railway, and suffered severely. The reconstruction of the line delayed the advance till the second weck of September, and it was on the 16th that the whole army was concentrated at Fereig ready for the final march upon Dongola.

On the 18th, it had reached the Nile bank near the lower part of the Third Cataract, which the gun-boats were ready to ascend-an casy matter in the actual state of the Nile. The Dervish position at Kerma was to be attacked next morning. The four brigades were formed in line of columns, the right resting on the river, the desert flank covered by the camel corps; the cavalry and the horse battery moving out in front; the gun-boats were working up the cataract. When Kerma was reached it was found that the Dervishes had all retired to the west bank.

It was soon discovered that they intended to try to stop the progress of the expedition at Hafir, where they had dug rifle pits along the river margin, and constructed a battery armed with five guns. Led by Colville the gun-boats forced their way past the battery, the Egyptian artillery co-operating by shelling the Dervish position from an island in the river. The enemy abandoned their camp in the night, the gun-boats having pushed on to Dongola.

Next day the Sirdar began to ferry his army across the river at Hafir, the very spot, by the way, where the British rear-guard crossed the Nile on retreat from Dongola in 1885. The Dervishes made some show of making a stand at Dongola town, but on the 23rd they retreated without fighting on the advance of the army. Numbers surrendered, others dispersed, the cavalry and camel corps pursued the utterly dispirited remnant, while the gun-boats steamed on to the head of the open water at Merowi, occupying Debbeh on the way. $\mathrm{Br}_{\mathrm{r}}$ the end of the month there was not a hostile Dervish in the Dongola province. Osman Azrak with a handful of those who escaped from Dongola was reported to be at the Wells of Abu Klea watching the old route of the desert column to Metemneh.

Dongola became the capital of the reconquered province. Frontier garrisons have been established at Debbeh, Ambukol, and Merowi, with posts of friendly natives guarding the desert wells 'on our side of the Bayuda. A reconnaissance pushed within fifty miles of Abu Hamed by Captain Broadwood reports that the Dervishes have now a very small garrison there.

The next stage in our march upon Khartoum will be the laying of a railway, a branch of the Soudan line, from near Halfa to Abu Hamed, the seizure of that place, and the launching on the Upper Nile, above the formidable cataracts that now bar our advance, of a gun-boat fotilla more numerous and more powerful than anything that has yet been scen on any African river. Our success so far, and the experience we have gathered, means that the way is now open to Khartoum, and that if the unforeseen does not come in to change the conditions of the problem, 
the barbarian standard that now flies over Khartoum and Omdurman will be hauled down before the world is much older, and Mahdism as a factor in African politics will be a thing of the past.

[At the conclusion of the lecture a number of photographic views taken by Captain Atteridge, and illustrative of the campaign, were exhibited.]

\section{NOTF TO LECTURE. \\ ENPENDITURE OF AMMUNITION.}

At the BATtLe of Ferkell and in the subsequent pursuit-

Horse Battery ( $\bar{j}$ secentimetre Krupp guns, throwing a projectile weighing $9 \cdot 46$ lbs.):-

$\begin{array}{lllll}\text { Common Shell } & - & - & - & 37 \\ \text { Shrapnel } & - & - & - & 50 \\ \text { Case - } & - & - & - & 4\end{array}$

Mule and Camel Batteries (6-centimetre Krupp guns, projectile weighing $7 \cdot 49$ lbs.):-

No. 2 Battery - 11 rounds per gun; also

30 " carbine, and

12 " revolver.

No. 3 , 11 " per gun.

Maxim " -350 ", ,

Infantry-Highest expenditure in any battalion, 17 rounds per rifle.

At the Battle of HafiR-

No. 1 Battery (Horse Battery) -47 rounds per gun.

No. 2 " - - - $\quad-31 \cdot 3$ " "

No. 3 " - - - -18 " "

Maxini " - - total -950 ,

Gun-boats at Hafir and Dongola-

"Tamai":-

9-pr. Armstrong, 114 rounds; 8 rockets; Nordenfeldt, 1,115 rounds ; ìnaxim, 800 rounds.

"Metemneh" :-

9-pr. Armstrong, 165 rounds; 2 rockets; $\mathrm{MI.-H}$. rifle, 1,910 rounds; Maxim, 1,500 rounds.

"Abu Klea":-

9-centimetre Krupp, 298 rounds; M.-H. rifle, 32 rounds; Nordenfeldt, 272 rounds; Maxim, 3,140 rounds.

"Zafir" (new gun-boat):-

$12 \frac{1}{2}$-pr. Q.F., 14 rounds; 6-pr. Q.F., 47 rounds ; Maxim, 12 rounds.

A. Hilliard Atteridge. 